\title{
Influence of pulp characteristics on the properties of alkali cellulose
}

\author{
Catharina Fechter $(\mathbb{D} \cdot$ Steffen Fischer $\cdot$ Felix Reimann · Harald Brelid • \\ Thomas Heinze $\mathbb{D}$
}

Received: 3 December 2019/Accepted: 6 April 2020/Published online: 9 June 2020

(C) The Author(s) 2020

\begin{abstract}
Alkali extraction of cellulose material is a common treatment for several industrial processesespecially the viscose process, which produces fibers for textile applications. This study investigated different generic dissolving wood pulps by means of alkali extraction (10-18 wt\% aq. $\mathrm{NaOH}$ at $\left.20-50{ }^{\circ} \mathrm{C}\right)$. The regenerated residue of the pulps was characterized for its chemical composition, molecular structure, and cellulose conformation. The investigated pulps had in common that glucan was most intensely extracted at low temperature and low concentration of aqueous alkali, xylan was most intensely extracted at high temperature and high concentration of aqueous alkali, and mannan was most intensely extracted at a concentration of aqueous alkali $>14 \mathrm{wtwt} \%$ at all temperatures applied. The degree of transformation via alkali cellulose to cellulose II as determined with
\end{abstract}

Raman spectroscopy was found to be maximized for all pulps at high alkali concentration and temperature had no major influence. Maximum yield for all investigated pulps was found when extraction was done with 18 wt $\%$ aq. $\mathrm{NaOH}$. The importance of temperature differed for the investigated pulps. The reason for the differences in extraction behavior or different absolute levels of resulting properties was found to be related to differences in the homogeneity and purity of the pulps. A conclusion of interest for industrial applications was that extracting the pulps with $18 \mathrm{wt} \%$ aq. $\mathrm{NaOH}$ led to an optimal alkalization result for yield, purity, and conversion. The steeping temperature chosen was found to be important to balance the yield and the purity of xylan-containing pulps.
C. Fechter $(\bowtie) \cdot T$. Heinze

Center of Excellence for Polysaccharide Research, Institute of Organic Chemistry and Macromolecular Chemistry, Friedrich-Schiller-University of Jena, Humboldtstraße 10, 07743 Jena, Germany

e-mail: catharina.fechter@uni-jena.de

S. Fischer · F. Reimann

Wood and Plant Chemistry, Technische Universität

Dresden, Pienner Str. 19, 01737 Tharandt, Germany

H. Brelid

Södra Skogsägarna Ekonomisk Förening, 43286 Väröbacka, Sweden 


\section{Graphic abstract}

\section{Properties of three alkali-extracted dissolving wood pulps}

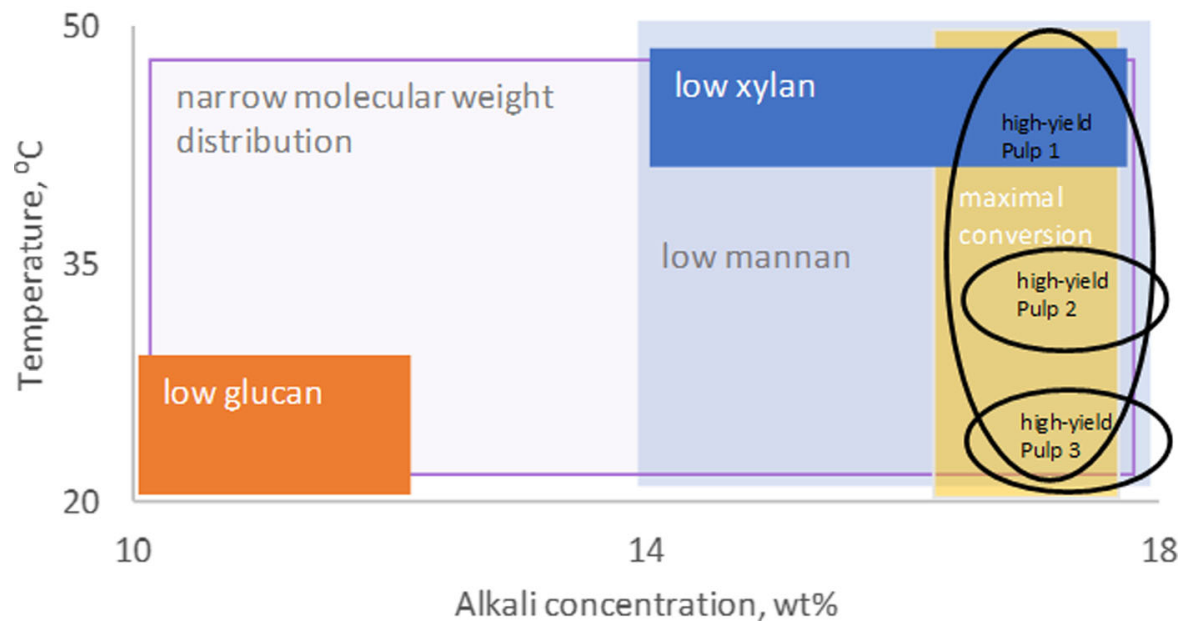

Keywords Dissolving wood pulp · Viscose . Alkalization · Raman - Lattice transformation $\cdot$ R18

\section{Introduction}

The demand for viscose fibers is increasing because of the increase in world population, prosperity as well as demand for fashion and other related consumer products. More than $90 \%$ of today's seven million tons of viscose fiber are produced using dissolving pulp derived from wood (DWP). Accordingly, this increasing demand is met by an extension of global DWP capacity. This capacity has almost doubled from 2008 to 2018 (Young 2018).

The first process step in producing viscose is the alkalization (steeping) and subsequent pressing of the pulp (Götze 1967). This treatment turns the pulp thoroughly into highly swollen alkali cellulose (NaCell). Na-Cell is able to react with carbon disulphide in the subsequent xanthation step. Moreover, Na-Cell is easy to depolymerize by means of the oxidation that occurs in the aging step prior to xanthation, which is done in order to adjust the degree of polymerization (DP) to the requirements of the viscose fiber product aimed for. A side effect of pressing the slurry of pulp and aqueous alkali is purification of the pulp dedicated for xanthation by means of alkali extraction. This process ensures, on one hand, the purification from short-chained, xanthation-chemical-consuming polymers. On the other hand, purification causes a yield loss for the viscose mill, which finally depends on the recovery strategy of the press lye.

Changes in the pulp induced through alkalization have been intensively considered in research and have been established and well described by Rydholm (1965), Fengel and Wegener (1989), Woodings (2001) and Sixta (2006a). When treating pulp with aqueous alkali and transforming the cellulose part into Na-Cell, two things happen: swelling of the entire solid polymer structure; and the dissolution of polymers with a low DP, i.e. hemicelluloses and low-molecular fractions of the cellulose. The intensity of these processes depends on the temperature and alkali concentration applied.

Cellulose is a heterogeneously structured polymer consisting of a mixture of low-ordered amorphous regions and highly-ordered crystalline regions. The amorphous regions are easily accessible when dispersed and swell in any polar solvent. This is not the case for crystalline regions. The amount of crystalline parts, indicated by the crystallinity index (CI), depends on the origin and pretreatments of the cellulose. Typical values for the CI of wood pulps determined with X-ray are 50-60\% (Sixta 2006b). Given the fact that reactions with cellulose take place at the hydroxyl groups at Position 2, 3 and 6, it is obvious that a high CI will decrease the reactivity as the amount of available hydroxyl groups becomes 
considerably lower. However, intracrystalline swelling of the structure in an alkaline medium converts crystalline cellulose into Na-Cell and breaks hydrogen bonds in the cellulose structure. This process makes the hydroxyl groups accessible for subsequent chemical reactions. Native cellulose exists as the specific lattice cellulose I (Cell I). When washing and neutralizing $\mathrm{Na}-\mathrm{Cell}$, and thus removing $\mathrm{NaOH}$, regeneration into the thermodynamically more stable crystal lattice of cellulose II (Cell II) takes place. An analysis of the change in content of Cell II before and after alkalization gives information on the resistance of a specific pulp to alkalization. Nevertheless, Fink et al. (1982) have discovered that the regeneration of partially alkalized pulp does not lead to the complete transition from Na-Cell to Cell II, as parts of the Na-Cell have been supposed to regenerate back to Cell I. It has been shown that this behavior is less pronounced in relative terms when more $\mathrm{Na}-\mathrm{Cell}$ is built. Rydholm (1965) has indicated an incomplete transformation of Na-Cell to Cell II upon regeneration as well and the explanation given has been the increase in amorphous cellulose.

At room temperature, intercrystalline swelling, i.e. filling the pores between the crystallites, passes into intracrystalline swelling at an alkali concentration of around $9 \mathrm{wt} \%$ aq. $\mathrm{NaOH}$. Intracrystalline swelling is completed at about $15 \mathrm{wt} \%$ (Rydholm 1965). Heuser and Bartunek (1925) and Saito (1939) have found a maximum total swelling of rayon at around $9 \mathrm{wt} \%$. Richter and Glidden (1940) identified 10-12 wt\% as the maximum for different wooden pulps and cotton linters. Total swelling levels off upon a further increase in alkali concentration when intracrystalline swelling takes place and intercrystalline swelling decreases. This is a result of competing reactions between cellulose, $\mathrm{H}_{2} \mathrm{O}$ and the $\mathrm{Na}^{+} \mathrm{OH}^{-}$dipole when reactants penetrate the cellulose structure (Klemm et al. 1998; Sixta 2006a). As swelling of cellulose is an exothermic process, increasing the temperature decreases the total swelling and increases the aqueous alkali concentration needed for obtaining a specific state of swelling (Saito 1939).

Swelling upon alkali treatment favors the dissolution of polymers in the pulp. The dissolved polymers, i.e. hemicelluloses and short-chained cellulose, can be removed easily by pressing. On one hand, exceeding the maximum of total swelling of the pulp by increased alkali concentration or temperature will decrease the amount of dissolvable carbohydrates as the mass transport will be sterically limited. On the other hand, chemical fragmentation reactions have been shown to appear at temperature levels $\geq 40{ }^{\circ} \mathrm{C}$ in combination with high alkali concentration of around $18 \mathrm{wt} \%$ aq. $\mathrm{NaOH}$ (Mozdyniewicz et al. 2014; Sixta et al. 2004). Fragmentation will create additional alkali-soluble substance, which decreases the process yield.

Regarding the viscose process, the optimal choice of steeping concentration and temperature is a balance between swelling, the extent of transformation to $\mathrm{Na}$ Cell, dissolution of short-chained polymers, which are removed with the lye through pressing, and the processability of both lye and Na-Cell. An early study (Wyatt 1966) has used an unspecified pulp when optimizing alkalization towards viscose quality and recommends steeping with $18.3 \mathrm{wt} \%$ aq. $\mathrm{NaOH}$ at $15{ }^{\circ} \mathrm{C}$ under $27 \mathrm{~min}$ as universally optimal process settings. A recent study (Reyes et al. 2016) has worked with a softwood sulphite dissolving pulp for viscose production by modelling the relation of alkali concentration, temperature and time towards yield and transformation to Na-Cell, i.e. the increase in Cell II. They have found the optimum for lattice transformation and yield to be $21 \mathrm{wt} \%$ aq. $\mathrm{NaOH}$ at $29^{\circ} \mathrm{C}$ under $45 \mathrm{~s}$. The short treatment time reflects the small influence of time during the alkalization of pulp as swelling occurs instantaneously (Rydholm 1965). The optimum has been at $45-50{ }^{\circ} \mathrm{C}$ if only the yield is considered.

Today, industrial steeping is commonly done in a slurry with $17-19$ wt $\%$ aq. $\mathrm{NaOH}$ at $45-55^{\circ} \mathrm{C}$ (Woodings 2001). Previous research studies have mostly referred to sheet steeping (Ellefsen 1955; Kolboe 1960; Kyrklund and Sihtola 1963; Sihtola and Nizovsky1963), but even the application of today's slurry alkalization has occurred in the past (Treiber et al. 1962). These studies have shown a clear tendency to refer to lower temperatures $\left(20-35{ }^{\circ} \mathrm{C}\right)$ fitting to the reported results of the optimization studies. A lower lye temperature is known to hamper processability by more viscous lye and more swollen Na-Cell. No former study has reported on influences of pulp characteristics when optimizing steeping conditions in the viscose process.

New pulp qualities have entered the market in the past decade to meet the growing demand for greater viscose production capacity. The difference in pulp qualities available results from the wood source used 
and the process and equipment applied. These factors challenge the viscose producer to focus on the relevant quality demands of new-coming pulps and to tune the process. Common practice is to control standardized key properties of the dissolving pulp, such as the average degree of polymerization, which is determined as intrinsic viscosity; hemicellulose content; resistance to alkaline extraction, which is determined as R18 and $\mathrm{R} 10$ at $20^{\circ} \mathrm{C}$; and the content of extractives and inorganics. It is difficult to track occurring production problems back to specific pulp qualities as it is common practice to mix several pulp qualities in the production of one viscose fiber product. The need to understand the optimization strategy of the industrial steeping process has been identified, and an approach is provided in the present study.

The aim of this study is to elaborate possibilities for the optimization of the alkalization step within the viscose process. Generic pulps and their different regenerated alkali cellulose ( $\mathrm{rAC}$ ) are described in detail in terms of their chemical composition and structure properties. The steeping settings applied reflect the settings of commonly used methods to describe the quality of DWP (10 and $18 \mathrm{wt} \%$ aq. $\mathrm{NaOH}$ at $20{ }^{\circ} \mathrm{C}$ ) and commonly used parameters in the industry $\left(18 \mathrm{wt} \%\right.$ aq. $\mathrm{NaOH}$ at $\left.35-50{ }^{\circ} \mathrm{C}\right)$.

\section{Experimental}

Materials

Six genetically different pulps were studied (Table 1). Two long-fiber pulps, originating from softwood, were selected: a sulphite pulp (LFs) that is used in the production of standard viscose staple fibers (VSF); and a highly pure long-fiber kraft pulp ( $L F k-h p)$ that is applied in the production of cellulose derivatives. Short-fiber pulps, originating from hardwood, were represented with a sulphite $(S F s)$ and two kraft pulps $(S F k, S F k-x)$ used in VSF production, as well as a paper-grade kraft pulp (SFk-paper). $S F k$ - $x$ possessed a somewhat elevated xylan content. Different regenerated alkali celluloses (rAC) were obtained using the procedure for the determination of alkali resistance (ISO 699:2015). The residue (R) obtained using the procedure was considered as $\mathrm{rAC}$.

Acetic acid 95-97\%, aq. $\mathrm{NaOH}$ p.a., water-free sodium acetate $\left(\mathrm{CH}_{3} \mathrm{COONa}\right)$ p.a., $\mathrm{L}(+)$-arabinose 99\%, D-xylose 99\%, D-(+)-mannose 99\%, D-(+)galactose $99 \%$, D-(+)-glucose $99,5 \%$, acetone p.a., BSTFA N,O Bis(trimethylsilyl)trifluoroacetamide/ trimethylsilyl TMCS 99:1, dihydrocholesterole (5 $\alpha$ cholestane-3 $\beta$-ol), 13-metylpentadecanoicsyra (anteiso-C16:0), pyridine, $\mathrm{HNO}_{3}$ p.a., $\mathrm{HCl}$ p.a., $\mathrm{La}_{2} \mathrm{O}_{3}$ p.a., $\mathrm{CsCl}$ p.a., copper ethylene-diamine solution (1.00 mol/l), $\mathrm{LiCl}$, and N,N-dimethylacetamide, $99.9+\%$, were purchased from Sigma Aldrich (Sweden).

\section{Methods}

Analysis of alkali resistance of pulps and the production of alkali cellulose

Alkali resistance (ISO 699:2015) of the pulps was determined as the R-value, and residues for further investigations were produced with 10, 14 and $18 \mathrm{wt} \%$ aq. $\mathrm{NaOH}$ at 20,35 and $50{ }^{\circ} \mathrm{C}$ according to the

Table 1 Fiber type, raw material, and production process of the pulps used in this study (Pöyry Management Consulting Oy 2017)

\begin{tabular}{llll}
\hline Sample $^{\mathrm{a}}$ & Fiber type & Raw material & Process $^{\mathrm{b}}$ \\
\hline LFk-hp & Long fiber & Pine & Kraft-Chlorine bleached \\
LFs & Long fiber & Pine/spruce & Sulphite-TCF \\
SFs & Short fiber & Eucalyptus (Dunii/Grandis) & Sulphite-ECF \\
SFk & Short fiber & Eucalypts (Urophylla) & Kraft-ECF \\
SFk-x & Short fiber & Birch/aspen & Kraft-ECF \\
SFk-paper & Short fiber & Birch/aspen & Kraft-TCF \\
\hline
\end{tabular}

${ }^{\mathrm{a}} \mathrm{LF}$, long fiber; SF, short fiber; s, sulphite; $\mathrm{k}$, kraft; hp, high purity; $\mathrm{x}$, high xylan

${ }^{\mathrm{b}} \mathrm{TCF}$, totally chlorine-free bleached; ECF, elemental chlorine-free bleached 
scheme given in Table 2. No further modifications from the standard procedure, ISO 699:2015, had to be considered when the alkali concentration was altered. When applying temperatures $>30{ }^{\circ} \mathrm{C}$, a finer glass filter $(40-100 \mu \mathrm{m})$ had to be used to compensate for the lower viscosity of the liquid. The residue $(\mathrm{R})$ was regenerated alkali cellulose (rAC) and was used for further investigations.

Analysis of pulps and regenerated alkali cellulose (rAC)

The carbohydrate composition was analyzed via acid hydrolysis (TAPPI-T $249 \mathrm{~cm}-85$ ) using $72 \mathrm{wt} \%$ aq. $\mathrm{H}_{2} \mathrm{SO}_{4}$. The acid-insoluble Klason lignin and acidsoluble lignin were determined, and the rest of the sample was assumed to be carbohydrates. The content of Klason lignin was determined gravimetrically. The content of acid-soluble lignin was determined from the hydrolysis filtrate after the removal of Klason lignin using UV spectroscopy at $205 \mathrm{~nm}$, assuming an absorptivity factor of $113 \mathrm{dm}^{3} \mathrm{~g}^{-1} \mathrm{~cm}^{-1}$ for hardwood pulps and $128 \mathrm{dm}^{3} \mathrm{~g}^{-1} \mathrm{~cm}^{-1}$ for softwood pulps. The liberated neutral monosaccharides in the hydrolysis filtrate were quantified using High-Performance Anion-Exchange Chromatography (HPAE ICS-3000 Dionex with Pulsed Amperometric Detection (PAD)) and reported as anhydrous carbohydrate according to SCAN-CM 71:09.

Intrinsic viscosity (limiting viscosity number) was analyzed according to ISO 5351:2010 based on the dissolution of the sample in copper ethylene-diamine solution (CED).

Molecular weight distribution was determined using GPC-MALS (solvent DMAc/LiCl) according to Henniges et al. (2011) on the following equipment: an RI detector (Waytt) Optilab T-rEX, a Multi Angle Light Scattering Detector (Waytt) Down Heleos II $(658 \mathrm{~nm})$, four columns (photoluminescence gel mixed A LS, $0.20 \mu \mathrm{m}, 7.5 \times 300 \mathrm{~mm}$ ) from Agilent. Data processing was done in Astra6 to calculate key values such as the weight-average degree of polymerization (DPw, DP), the polydispersity index (PDI), and the weight fraction of molecules with DP $<100$.

NIR FT Raman spectroscopy was performed using a MultiRam III (Bruker) with a liquid-nitrogen-cooled Ge diode as the detector. A Nd:YAG laser (1064 nm) with a maximum power of $500 \mathrm{~mW}$ was the light source for the excitation of the Raman scattering. Because of the solid and compact structure of the residues, no further sample preparation was necessary. A total of eight points per sample was measured. Each point was measured 100 times. The data was collected and analyzed using OPUS software. All spectra of one sample were combined into one, and this averaged spectrum was then handled with OriginPro. Amorphous cellulose, cellulose I and cellulose II were calculated according to Schenzel et al. (2005), Schenzel et al. (2009) and Agarwal (2017).

Table 2 Preparation of residues from pulp samples as regenerated alkali cellulose for further investigations, $\mathrm{x}$

\begin{tabular}{|c|c|c|c|c|c|c|c|c|c|}
\hline Sample $^{\mathrm{a}}$ & $\mathrm{R} 10 / 20$ & R10/35 & $\mathrm{R} 10 / 50$ & $\mathrm{R} 14 / 20$ & $\mathrm{R} 14 / 35$ & $\mathrm{R} 14 / 50$ & $\mathrm{R} 18 / 20$ & $\mathrm{R} 18 / 35$ & $\mathrm{R} 18 / 50^{\mathrm{b}}$ \\
\hline LFk-hp & (x) & & & & & & (x) & & $\mathrm{x}$ \\
\hline LFs & $\mathrm{x}$ & $\mathrm{x}$ & $\mathrm{x}$ & $\mathrm{x}$ & $\mathrm{x}$ & $\mathrm{x}$ & $\mathrm{x}$ & $\mathrm{x}$ & $\mathrm{x}$ \\
\hline SFs & (x) & & & & & & (x) & & $\mathrm{x}$ \\
\hline SFk & $\mathrm{x}$ & $\mathrm{x}$ & $\mathrm{x}$ & $\mathrm{x}$ & $\mathrm{x}$ & $\mathrm{x}$ & $\mathrm{x}$ & $\mathrm{x}$ & $\mathrm{x}$ \\
\hline SFk-x & $\mathrm{x}$ & $\mathrm{x}$ & $\mathrm{x}$ & $\mathrm{x}$ & $\mathrm{x}$ & $\mathrm{x}$ & $\mathrm{x}$ & $\mathrm{x}$ & $\mathrm{x}$ \\
\hline SFk-paper & (x) & & & & & & (x) & & $x$ \\
\hline
\end{tabular}

(x) only determination of alkali resistance; cf. Table 1 for the denotation of the samples

${ }^{a} \mathrm{LF}$, long fiber; SF, short fiber; s, sulphite; $\mathrm{k}$, kraft; hp, high purity; $\mathrm{x}$, high xylan

${ }^{\mathrm{b}} \mathrm{R}$, residue after alkali extraction; 10, 14 resp. 18, concentration in wt\% aq. $\mathrm{NaOH}$ used for alkali extraction; 20, 35 resp. 50 , temperature in ${ }^{\circ} \mathrm{C}$ used for alkali extraction 


\section{Results and discussion}

Change in chemical composition of pulp caused by alkalization

The pulps investigated contained a wide variety of hemicellulose (Table 3). The lowest mannan content was found in the short-fiber pulps $S F s, S F k, S F k-x$ and $S F k$-paper. These pulps had three different levels of xylan content, and two of them were investigated in detail for different alkalization settings ( $S F k$ and $S F k$ $x$, Table 2). The long-fiber pulps possessed two mannan levels. The pulp with the highest hemicellulose content was chosen for detailed investigation $(L F s)$. The high level of cellulose II (Cell II) in $L F k-h p$ was supposed to be connected to the high purity level with regard to hemicellulose, which often demands an alkaline purification step in the fiber line. In a comparison of dissolving pulp qualities, the polydispersity index PDI for the sulphite pulps was found to be significantly higher than that for the kraft pulps, resulting in generally low levels of R-values for the sulphite pulps. This is according to literature (Sixta 2006b). SFk-paper had an even higher PDI, which can be explained by the high level of xylan.

Considering the residue after alkaline treatment, $L F s$, $S F k$, and $S F k-x$ showed the same extraction behavior when treated with aq. $\mathrm{NaOH}$ (Fig. 1). The increasing alkali concentration used for extraction of the pulps $(10,14$, and $18 \mathrm{wt} \%$ aq. $\mathrm{NaOH})$ resulted in increasing residue levels expressed as R-values when the pulps were extracted at 20 and $35^{\circ} \mathrm{C}$. Lye with an increasing concentration exceeding $10-12 \mathrm{wt} \%$ is known to swell the structure of the pulp less (Richter and Glidden 1940), thereby extracting less material from the pulp (Sixta 2006a; Fengel and Wegener

Table 3 Properties of the investigated pulps

\begin{tabular}{|c|c|c|c|c|c|c|c|}
\hline Sample $^{\mathrm{a}}$ & & LFk-hp & LFs & SFs & SFk & SFk-x & SFk-paper \\
\hline \multicolumn{8}{|c|}{ Chemical composition $^{\mathrm{b}}$} \\
\hline Glucan & $\mathrm{mg} \mathrm{g}^{-1}$ & 980 & 960 & 968 & 970 & 954 & 746 \\
\hline Xylan & $\mathrm{mg} \mathrm{g}^{-1}$ & 7 & 14 & 23 & 21 & 37 & 225 \\
\hline Mannan & $\mathrm{mg} \mathrm{g}^{-1}$ & 8 & 21 & 3 & 2 & 4 & 3 \\
\hline Klason lignin & $\mathrm{mg} \mathrm{g}^{-1}$ & 0 & 0 & 1 & 0 & 0 & 9 \\
\hline Acid-soluble lignin & $\mathrm{mg} \mathrm{g}^{-1}$ & 3 & 4 & 5 & 5 & 4 & 10 \\
\hline \multicolumn{8}{|l|}{ Molecular structure } \\
\hline Intrinsic viscosity & $\mathrm{ml} \mathrm{g}^{-1}$ & 641 & 560 & 516 & 417 & 391 & 780 \\
\hline $\mathrm{DPw}(\mathrm{SEC})^{\mathrm{c}}$ & & 2104 & 1752 & 1414 & 1132 & 1048 & 2752 \\
\hline $\mathrm{PDI}^{\mathrm{d}}$ & & 3.1 & 6.4 & 5.9 & 3.1 & 2.8 & 7.6 \\
\hline $\mathrm{C}_{\mathrm{a}}\left(\operatorname{Raman}^{\mathrm{e}}\right)$ & $\%$ & 47 & 54 & 53 & 52 & 52 & 53 \\
\hline Cell I (Raman) & $\%$ & 25 & 43 & 44 & 47 & 43 & 43 \\
\hline Cell II (Raman) & $\%$ & 28 & 3 & 3 & 1 & 5 & 4 \\
\hline \multicolumn{8}{|l|}{ Alkali resistance } \\
\hline $\mathrm{R} 10 / 20^{\mathrm{f}}$ & wt $\%$ & 97.5 & 90.1 & 91.0 & 93.4 & 93.4 & 87.8 \\
\hline $\mathrm{R} 18 / 20$ & wt $\%$ & 98.4 & 94.4 & 95.2 & 96.7 & 96.9 & 90.7 \\
\hline $\mathrm{R} 18 / 50$ & $\mathrm{wt} \%$ & 98.1 & 94.3 & 94.8 & 96.5 & 95.3 & 76.1 \\
\hline R18/20-R18/50 & wt $\%$ & 0.3 & 0.1 & 0.4 & 0.2 & 1.6 & 14.6 \\
\hline
\end{tabular}

${ }^{\mathrm{a}} \mathrm{LF}$, long fiber; SF, short fiber; s, sulphite; $\mathrm{k}$, kraft; hp, high purity; $\mathrm{x}$, high xylan

${ }^{\mathrm{b}}$ Saccharides are reported as pure anhydrous polysaccharides. Ash content is not reported

${ }^{\mathrm{c}}$ Weight average degree of polymerization determined with size-exclusion chromatography

${ }^{\mathrm{d}}$ Polydispersity index determined with size-exclusion chromatography

${ }^{\text {e}}$ Parameter of cellulose structure measured with Raman spectroscopy and evaluated according to Agarwal (2017) as a fraction of total cellulose. $\mathrm{C}_{\mathrm{a}}$, amorphous cellulose; Cell I, cellulose I; Cell II, cellulose II

${ }^{\mathrm{f}} \mathrm{R}$, R-value as residue after alkaline extraction; 10 or 18 , wt $\%$ aq. $\mathrm{NaOH}$ used for extraction; 20 or 50 , extraction temperature in ${ }^{\circ} \mathrm{C}$ 


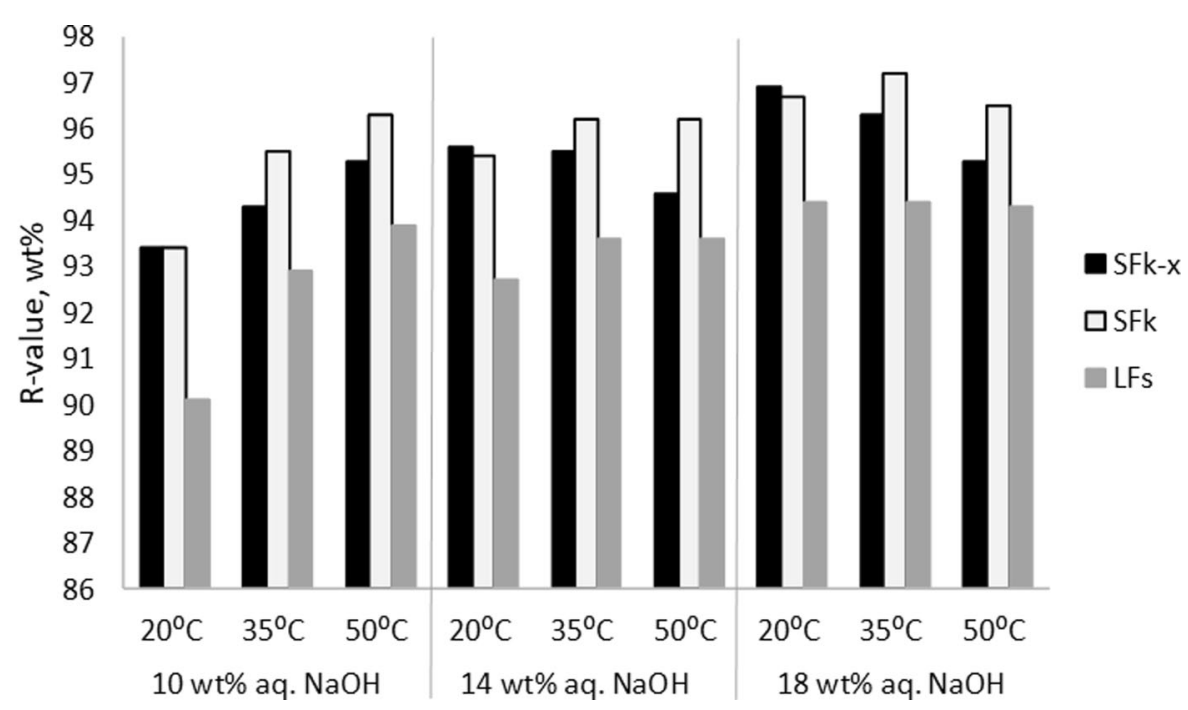

Fig. 1 Residue, expressed as R-value upon extraction of pulp with aqueous $\mathrm{NaOH}$ at different concentrations and temperatures. $\mathrm{LF}-$ long fiber, SF-short fiber, s-sulphite, $\mathrm{k}$ - kraft, $\mathrm{x}$ - high xylan

1989). Increasing temperature is known to swell polymeric structures less, too, and increasing temperature counteracts the extraction of material (Sixta 2006a; Fengel and Wegener 1989). Consequently, extraction at $20{ }^{\circ} \mathrm{C}$ resulted in a lower R-value than extraction at $35^{\circ} \mathrm{C}$. However, the R-values after alkali extraction at $50{ }^{\circ} \mathrm{C}$ cannot be described by the mechanism discussed above. The differences in extracted substance for each pulp became smaller when the aqueous alkali concentration was increased at $50{ }^{\circ} \mathrm{C}$, and all pulps yielded the lowest R-value after extraction with $14 \mathrm{wt} \%$ aq. $\mathrm{NaOH}$. Different properties of $L F S$, $S F k$, and $S F k-x$ upon alkali extraction became visible when the influence of temperature on the R-value obtained at different alkali concentrations was analyzed. The R-value when increasing temperature changed from increasing $\mathrm{R}$-value at a low alkali concentration to decreasing $\mathrm{R}$-value at a high alkali concentration. $S F k-x$ changed already at $14 \mathrm{wt} \%$ aq. $\mathrm{NaOH}$ to decreasing R-value, $S F k$ at $18 \mathrm{wt} \%$, and $L F S$ remained constant even at the highest alkali concentration applied. LFs showed the absolute maximum of R-value at $18 \mathrm{wt} \%$ aq. $\mathrm{NaOH}$ at any temperature applied. $S F k$ reached a maximum R-value at $18 \mathrm{wt} \%$ and $35^{\circ} \mathrm{C}$, and $S F k-x$ at $18 \mathrm{wt} \%$ and $20^{\circ} \mathrm{C}$.

It was found that less xylan was extracted from $S F k$ $x$ at 20 and $35^{\circ} \mathrm{C}$ when the alkali concentration was increased, which corresponds to the increase in
R-value at the same settings (Fig. $2 \mathrm{a}-\mathrm{c}$ ). At $50{ }^{\circ} \mathrm{C}$, more xylan was extracted when the alkali concentration was increased to 14 or $18 \mathrm{wt} \%$ aq. $\mathrm{NaOH}$. Accordingly, the most xylan was retained after extraction at a high alkali concentration and at a low temperature, the least xylan was retained after extraction at a high alkali concentration and a high temperature. $S F k$, which contained less xylan than $S F k-x$, showed the same behavior but less pronounced. Extracting LFs, where mannan was the main hemicellulose component, the absolute loss of both xylan and mannan was maximal when using 14 or $18 \mathrm{wt} \%$ aq. $\mathrm{NaOH}$ alkali concentration at any temperature applied. The extraction behavior for $L F s, S F k$, and $S F k-x$ had in common that glucan was the most intensely extracted component at a low temperature and a low concentration of alkali $\left(20{ }^{\circ} \mathrm{C}\right.$ and $10 \mathrm{wt} \%$ aq. $\mathrm{NaOH}$ ), xylan was the most intensely extracted at a high temperature and a high concentration of alkali $\left(50{ }^{\circ} \mathrm{C}\right.$ and $>14 \mathrm{wt} \%$ aq. $\left.\mathrm{NaOH}\right)$, and mannan was the most intensely extracted at an alkali concentration $>14 \mathrm{wt} \%$ aq. $\mathrm{NaOH}$ at all temperatures applied.

Sixta and Schrittwieser (2004)have investigated the properties of a beech sulphite pulp upon extraction with aqueous alkali at different temperatures. The key properties of this pulp were found to be equal to the SFK- $x$ of the present study (R18 93.4\%; $4.0 \%$ xylan). Those authors have found that xylan removal has been 


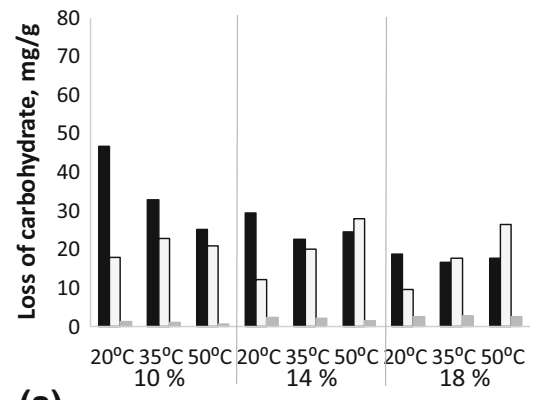

(a)

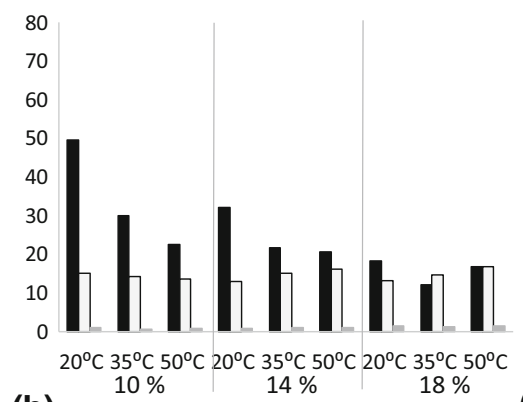

(b)

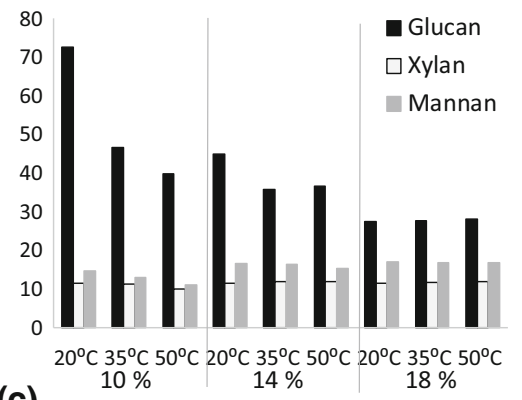

(c)

Fig. 2 a-c Loss of carbohydrates in the residue after extraction of pulp with aqueous $\mathrm{NaOH}$ at different concentrations and temperatures. a SFk-x—short-fiber kraft pulp with high xylan; b SFK—-short-fiber kraft pulp; c LFs-long-fiber sulphite pulp

more efficient at $20{ }^{\circ} \mathrm{C}$ than at higher temperatures as the alkali concentration has had to be increased from 100 to $150 \mathrm{~g} / \mathrm{l}$ to reach the lowest possible xylan content in the pulp at 50 and $80{ }^{\circ} \mathrm{C}$. The present study confirms that extraction maximum at low temperatures $\left(20\right.$ and $\left.35^{\circ} \mathrm{C}\right)$ can be expected with $10 \mathrm{wt} \%$ aq. $\mathrm{NaOH}$ (Fig. 3), which highlights that a higher temperature $\left(50^{\circ} \mathrm{C}\right)$ results in even higher levels of xylan extraction when the alkali concentration is increased from 10 to 14 and $18 \mathrm{wt} \%$ aq. NaOH. LFs, SFk and $S F k-x$ seemed to have different extraction optima, however, that was not possible to be exactly determined in this study. $S F k-x$, with the highest initial xylan content, illustrated the process of xylan removal upon alkalization within the investigated settings in

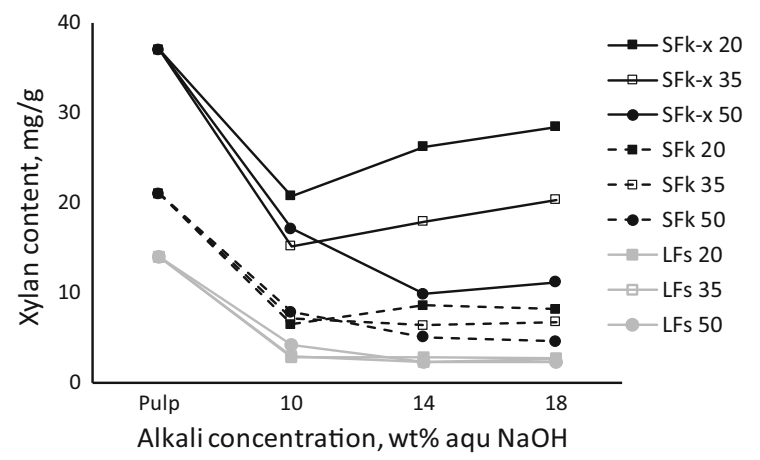

Fig. 3 Profiles of xylan content in the regenerated residue of three different pulps after alkaline extraction at different concentrations and temperatures $(10,14$ and $18 \mathrm{wt} \%$ aq. alkali; 20,35 and $\left.50{ }^{\circ} \mathrm{C}\right)$. LF-long fiber, SF-short fiber, s-sulphite, $\mathrm{k}$-kraft, $\mathrm{x}$ - high xylan. 20,35 resp. 50 -temperature in ${ }^{\circ} \mathrm{C}$ used for alkali extraction accordance with Sixta and Schrittwieser; the lower the extraction temperature, the lower the alkali concentration needed to reach a maximum in xylan extraction from pulp. $S F k$ and $L F s$ with lower initial contents of xylan are assumed to develop in the same way but to a less pronounced extent.

The study considered an even wider variety of pulps by applying a minimized trial scheme (Table 3 ). This trial scheme included the standard extraction settings for the evaluation of dissolving pulp, R18 and R10 at $20{ }^{\circ} \mathrm{C}$ (R18/20 and R10/20), and R18 at $50{ }^{\circ} \mathrm{C}$ (R18/ 50 ), as this setting was seen to be relevant for today's production of viscose staple fiber. The higher amount of extracted material from the pulp indicated by the lower R-value due to extraction at a low alkali concentration (R10/20) or a higher temperature and a high alkali concentration (R18/50) was confirmed for all pulps investigated (Table 3 ). The difference between $\mathrm{R} 10 / 20$ and $\mathrm{R} 18 / 20$ is considered to be related to PDI, where a large difference indicates a wide PDI (Sixta 2006b). The present study could not clearly show this relationship, which might be due to the different viscosity levels and process histories of the investigated pulps. Nevertheless, the effect of high temperature combined with a high alkali concentration on the decrease of residue, in comparison to extraction at low temperature (R18/50:R18/20), was correlated to the hemicellulose content present in the pulp (Table 3). This was found for short-fiber pulps, in particular. 
The change in carbohydrate structure caused by alkalization

\section{Molecular weight}

After alkaline extraction, all pulps obtained a decreased amount of material with DP $<50$ and $<$ 100 , as this fraction was removed in the form of hemicellulose and low molecular-mass cellulose (Table 4 and Fig. 2). Furthermore, a slight chemical degradation of the carbohydrates at $50{ }^{\circ} \mathrm{C}$ could be expected according to data in the literature (Mozdyniewicz et al. 2013, Sixta et al. 2004 and Sixta 2006a). The data of this study showed no clear difference in polymer degradation due to temperature or alkali concentration. The relative increase in the fraction of DP $>2000$ for all pulps was, instead, a consequence of the decrease in the fraction of lowmolecular-weight substance after extraction (Table 4). The corresponding distribution of molecular weight shown in the "Appendix" (Fig. 6) illustrates how the material of high molecular weight was successively degraded to a lower molecular weight, which led to a decrease in Mw. This successive degradation was less pronounced for the short fiber kraft pulps. Kraft pulps had a lower PDI than the sulphite pulps, which resulted in less material to be degraded and extracted. A degradation of intercrystalline-available low molecular-weight hemicelluloses could not be followed in this study, as those degraded molecules had left the sample upon pressing. This possible degradation could explain the increased extraction of xylan from pulp at high alkali concentrations and temperatures. The extraction with $10 \mathrm{wt} \%$ aq. $\mathrm{NaOH}$ at $20{ }^{\circ} \mathrm{C}(10 / 20)$ counted for the highest decrease in low-molecular-weight substances and can most likely be related to the large decrease in glucan at low alkali concentrations and temperatures (Fig. 2).

The extraction of substance of low-molecular mass is supposed to decrease PDI. This became obvious for $L F s$, in which PDI decreased from 6.4 in the raw material to below 4.0 in the extracted samples. PDI in SFk decreased, to a lesser extent, from 3.1 to significantly below 3.0. The minor decrease in PDI of $S F k-x$, which had a low initial PDI of 2.8, highlights that the extracted substance (3.1-6.6 wt \% according to the determined R-values, Fig. 1) had a molecular weight distribution that extended into the high molecular weight fraction. No further general explanations for the differences between the different extraction settings in the investigated pulps could be found.
Table 4 Molecularweight-related properties of pulps and their alkali extracts determined with size-exclusion chromatography. Molecular weight distributions are shown in the "Appendix" (Fig. 6)

${ }^{\mathrm{a}} \mathrm{LF}$, long fiber; SF, short fiber; s, sulphite; $k$, kraft; $x$, high xylan; xx/yy, 10 or 18 wt $\%$ aq. $\mathrm{NaOH}, 20$ or $50{ }^{\circ} \mathrm{C}$ used for extraction

${ }^{\mathrm{b}}$ Polydispersity index (Mw/ Mn)

${ }^{\mathrm{c}}$ Degree of polymerization

\begin{tabular}{llllll}
\hline Sample $^{\mathrm{a}}$ & $\mathrm{M}_{\mathrm{w}}, \mathrm{kg} \mathrm{mol}^{-1}$ & $\mathrm{PDI}^{\mathrm{b}}$ & $\mathrm{DP}^{\mathrm{c}}<50, \%$ & $\mathrm{DP}<100, \%$ & $\mathrm{DP}>2000, \%$ \\
\hline LFs & 284 & 6.4 & 3.2 & 7.3 & 25.8 \\
LFs 10/20 & 246 & 3.2 & 0.2 & 1.1 & 30.0 \\
LFs 10/50 & 248 & 3.6 & 0.4 & 1.9 & 29.9 \\
LFs 18/20 & 238 & 3.9 & 0.7 & 2.6 & 29.4 \\
LFs 18/50 & 213 & 3.5 & 0.6 & 2.6 & 26.3 \\
SFk & 183 & 3.1 & 1.8 & 4.7 & 13.3 \\
SFk 10/20 & 168 & 2.3 & $<0.1$ & 0.6 & 17.3 \\
SFk 10/50 & 153 & 2.7 & 0.6 & 2.3 & 15.3 \\
SFk 18/20 & 165 & 2.7 & 0.4 & 1.9 & 17.8 \\
SFk 18/50 & 158 & 2.4 & 0.1 & 1.3 & 16.1 \\
SFk-x & 155 & 2.8 & 1.1 & 3.9 & 12.4 \\
SFk-x 10/20 & 165 & 2.7 & 0.3 & 1.8 & 16.9 \\
SFk-x 10/50 & 158 & 2.6 & 0.3 & 1.7 & 15.6 \\
SFk-x 18/20 & 156 & 2.8 & 0.4 & 2.6 & 15.8 \\
SFk-x 18/50 & 151 & 2.7 & 0.5 & 2.3 & 14.6 \\
\hline
\end{tabular}




\section{Transformation of cellulose I to cellulose II}

The transformation of cellulose I (Cell I) to Cell II upon the regeneration of alkalized pulp (rAC) is a measure of the transformation of Cell I to alkali cellulose by alkalization and, consequently, a measure of the reactivity of the pulp. Röder et al. (2006) have reported FT-Raman to be a fast and precise method in comparison to wide-angle X-ray scattering, which is the standard method for determining the crystallinity of Cell II. Schenzel et al. (2009) and Agarwal (2017) have proposed different approaches using Raman spectroscopy for the determination of Cell II in the crystalline part of a sample. Schenzel et al. have used the ratio of the intensities I at $1477-1464 \mathrm{~cm}^{-1}$ and at 379-352 $\mathrm{cm}^{-1}$, Fig. 4. Agarwal (2017) has used the ratio $577-1096 \mathrm{~cm}^{-1}$. Even though Agarwal's approach is dedicated to characterizing nanofibrillated cellulose, these three approaches correlated well to each other when the data obtained in the present study were used. The approach given by Agarwal (Eq. 1) was chosen for this evaluation. The change of intensity at $577 \mathrm{~cm}^{-1}$, which clearly illustrates the structural change of the cellulose when applying the different alkalization settings in the present study, is shown in the "Appendix" (Fig. 7). The evaluation was complemented with the approach for amorphous cellulose $\mathrm{C}_{\mathrm{a}}$ from the same reference (Eq. 2), and the completion to $100 \%$ was interpreted as the proportion of Cell I (Eq. 3). This value for Cell I was, on average, $8 \%$ units lower than the Raman crystallinity index $\mathrm{Xc}_{\text {Raman }}$ established by Schenzel et al. (2005) (Cell I = 1.0422 $\mathrm{Xc}_{\text {Raman }}-8.032$. $\left.\mathrm{R}^{2}=0.9841\right)$. The approach by Schenzel et al. (2005) uses the ratio of the intensities at $1481 \mathrm{~cm}^{-1}$ and $1462 \mathrm{~cm}^{-1}$ as an expression for the degree of crystallinity of partially crystalline Cell I samples.

Cell II $[\%$ of crystalline share $]=\frac{\frac{I_{577}}{I_{1096}}-0.009}{0.0013}$

$C_{a}[\%$ of total cellulose $]=\frac{I_{1380}}{I_{1096}} \times 100$

Cell I [\% of total cellulose $]$

$$
=\left(100-C_{a}\right) \times \frac{100-\text { Cell II }}{100}
$$

The degree of transformation $\left(\mathrm{D}_{\mathrm{T}}\right)$ of the pulp into alkali cellulose was calculated as an increase in Cell II upon alkalization and regeneration (Eq. 4).

$D_{T}=\frac{100 \times\left(\text { Cell } I I_{r A C}-\text { Cell } I I_{D W P}\right)}{100-\text { Cell } I I_{D W P}}$

According to the literature, alkali concentrations of $\geq 16 \mathrm{wt} \%$ aq. $\mathrm{NaOH}$ at $20^{\circ} \mathrm{C}$ lead to the complete transformation of Cell I to Cell II upon regeneration (Sisson and Saner 1941; Fink et al. 1982). The highest $\mathrm{D}_{\mathrm{T}}$ achieved in this study was only $93 \%$ (Fig. 5). This points to the relative character of Raman spectroscopy and the need for the calibration of specific series when using this technique. The relative difference between the investigated settings and the different pulps can be evaluated well, despite this issue. The transformation of Cell I to Cell II increased with increasing alkali concentration and decreasing temperature. This result is in line with findings by Sisson and Saner (1941) and Reyes et al. (2016). A clear ranking of the severity of the increase in alkalization in terms of conformation
Fig. 4 Raman spectra of the long-fiber sulphite pulp (LFs) in native form and after alkaline extraction with $18 \mathrm{wt} \%$ aq. $\mathrm{NaOH}$ at $50{ }^{\circ} \mathrm{C}$ (LFs 18/50). Bands of interest for evaluation of cellulose structure are marked

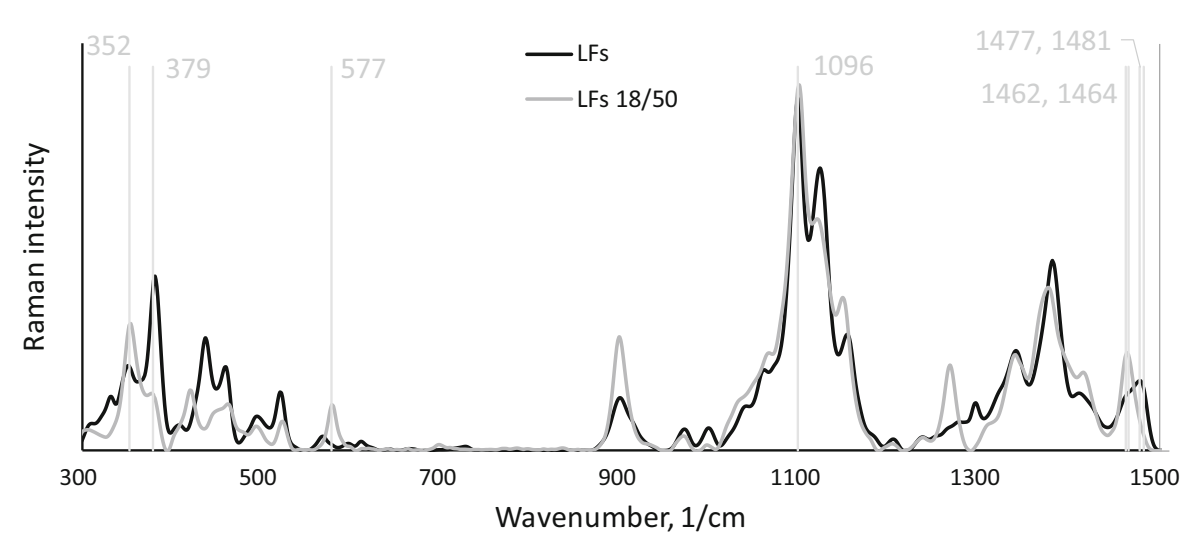


Fig. 5 Transformation of Cell I to Cell II of different pulps (LF-long fiber, SFshort fiber, s-sulphite, $\mathrm{k}$ kraft, $\mathrm{x}$-high xylan) upon alkalization at different concentrations and temperatures; concentration of aqueous $\mathrm{NaOH}: 10,14$ or $18 \mathrm{wt} \%$; temperature 20, 30 , or $50{ }^{\circ} \mathrm{C}$. The accuracy of the measurement is assumed to $\pm 5 \%$-units

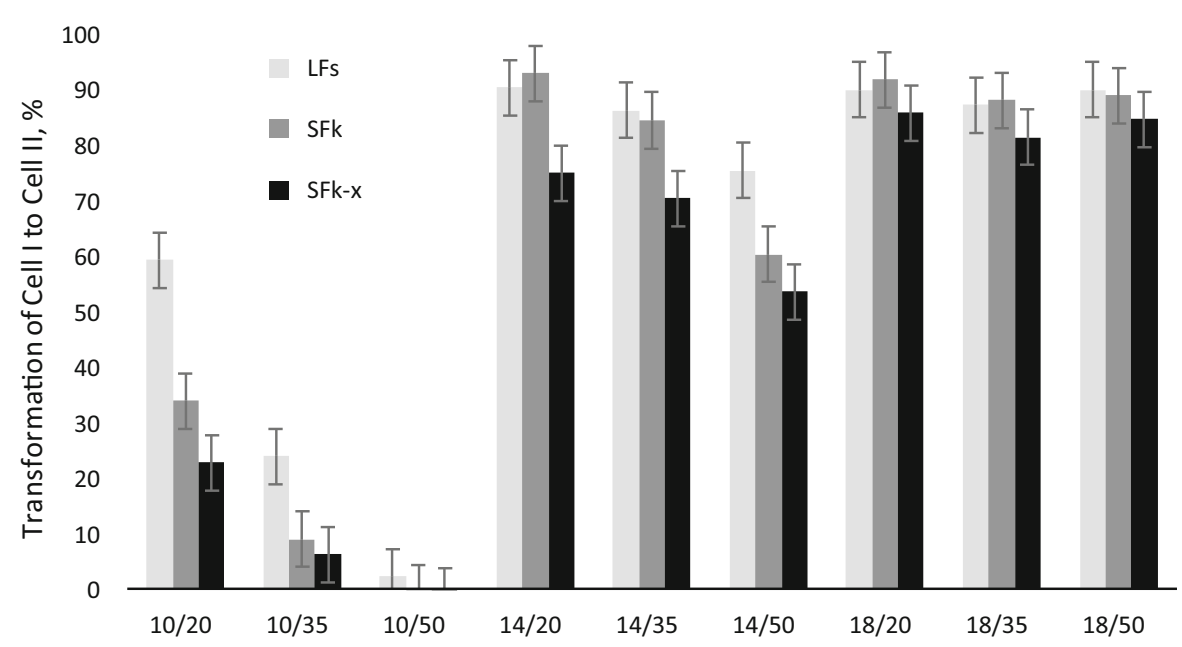

transformation was given by concentration $(10<14<18$ wt $\%$ aq. $\mathrm{NaOH})$. A ranking by temperature was less pronounced and most obvious at 10 and $14 \mathrm{wt} \%$ aq. $\mathrm{NaOH}\left(50<35<20^{\circ} \mathrm{C}\right)$. A transformation at 10/50 was hardly recognizable for any of the pulps and was found to be the weakest treatment followed by 10/35, 10/20 and 14/50. At these treatments, $L F s$ was distinguished as the most reactive pulp. This finding is in accordance with the observations of Sixta and Borgards (1999), where acid sulfite pulps have been found to require a lower lye concentration for the lattice transformation to Na-Cell than kraft pulps. At harsher conditions (14/35 and 14/20), $S F k$ reached the same level as LFs. These pulps showed a tendency toward a higher proportion of $\mathrm{C}_{\mathrm{a}}$ or a lower proportion of Cell II (Table 3), which might contribute to an easier conversion. At $18 \mathrm{wt} \%$ aq. $\mathrm{NaOH}$, temperature had less influence on this transformation, and only minor differences in reactivity among the investigated pulps could be seen. For $L F S$ and $S F k$, a maximum of transformation was achieved using $14 \mathrm{wt} \%$ aq. $\mathrm{NaOH}$ at $20{ }^{\circ} \mathrm{C}$. $S F k-x$ reached that transformation level at $18 \mathrm{wt} \%$ aq. $\mathrm{NaOH}$. The earlier and more pronounced transformation of $L F s$ and $S F k$ can be related to the highest degree of $\mathrm{C}_{\mathrm{a}}(L F s)$ and the lowest degree of Cell II (SFk) (cf. Table 3), which are supposed to favor the reactivity of a pulp.
Optimizing the alkalization step

The present study identified typical differences between conventional dissolving wood pulp (DWP) and, thus, room for process optimization in the process step of steeping with alkali. The long-fiber sulphite pulp $(L F s)$ with an initially low content of xylan and high PDI reached the highest purity from hemicelluloses (7-8 mg/g, cf. Table 3 and Fig. 2c) when it was extracted with 14 or $18 \mathrm{wt} \%$ aq. $\mathrm{NaOH}$. For this pulp, the yield, determined as R-value, varied from 90.1 to $94.4 \%$ with the conditions applied (Fig. 1). This large variation emphasizes the need for optimizing steeping conditions in order to minimize loss in yield. A maximum yield of $>94 \%$ was reached using $18 \mathrm{wt} \%$ aq. $\mathrm{NaOH}$. The R-value was not affected by temperature at this alkali concentration. The short-fiber kraft pulps with low PDI and low and high initial content of xylan ( $S F k$ and $S F k-x$, respectively) reached the highest purity from hemicelluloses with 14 or 18 wt $\%$ aq. $\mathrm{NaOH}$ at $50{ }^{\circ} \mathrm{C}$ (5-6 resp. $12-13 \mathrm{mg} / \mathrm{g}$, cf. Table 3 and Fig. 2a, b). Residual xylan in $S F k-x$ varied between 12 and $30 \mathrm{mg} / \mathrm{g}$ over the entire investigated range of conditions, which underlines the importance of optimizing this property when steeping. A maximum yield of $>96 \%$ for both short-fiber kraft pulps was reached using $18 \mathrm{wt} \%$ aq. $\mathrm{NaOH}$ at 20 or $35^{\circ} \mathrm{C}$ ( $S F k-x$ resp. $S F k$ ). Molecular weight distribution was not critical when steeping the three pulps. All settings produced a regenerated $\mathrm{AC}(\mathrm{rAC})$ with decreased or 
low PDI. The maximum transformation of $L F s$ and $S F k$ to Cell II via Na-Cell occurred already with 14 wt $\%$ aq. $\mathrm{NaOH}$ at 20 and $35{ }^{\circ} \mathrm{C}$. SF $k$ - $x$ needed $18 \mathrm{wt} \%$ aq. $\mathrm{NaOH}$ for the maximum transformation. $L F s$ stood out as the pulp most robust for steeping conditions. High purity and a transformation to $\mathrm{Na}$-Cell were achieved with 14 wt\% aq. $\mathrm{NaOH}$ at 20 or $35^{\circ} \mathrm{C}$. For the sake of yield optimization, a higher alkali concentration at a temperature between 20 and $50{ }^{\circ} \mathrm{C}$ would be preferable. Steeping $S F k$, and especially $S F k-x$, with 18 wt $\%$ aq. $\mathrm{NaOH}$ at different temperatures would compromise either yield or purity while the transformation to Na-Cell would be at the maximum. Extracting $3 \mathrm{mg} / \mathrm{g}$ or $0.3 \%$ more xylan from $S F k$ while increasing the temperature from 35 to $50{ }^{\circ} \mathrm{C}$ decreased yield by $0.7 \%$-units, which is $0.4 \%$ additional yield loss caused by the extraction of other carbohydrates. Yield should be optimized using a temperature $<50{ }^{\circ} \mathrm{C}$. $S F k-x$ behaved similarly, but on a higher absolute level of property changes, which makes optimization of the settings more important. High alkali (18 wt \% aq. $\mathrm{NaOH})$ is necessary for the maximum transformation to Na-Cell. Extracting $17 \mathrm{mg} / \mathrm{g}$ or $1.7 \%$ more xylan while increasing the temperature from 20 to $50{ }^{\circ} \mathrm{C}$ decreased the yield by $1.6 \%$-units, which means no further yield loss caused by the extraction of other carbohydrates. Purity should be optimized using a temperature $>20{ }^{\circ} \mathrm{C}$.

An illustration of the yield-purification relationship among the different investigated pulps based on the discussed data is shown in the "Appendix" (Fig. 8).

\section{Conclusions}

It was found that different pulps followed the same general extraction behavior for chemical composition and carbohydrate structure when treated with aqueous alkali (10-18 wt $\%$ aq. $\mathrm{NaOH}$ at $\left.20-50{ }^{\circ} \mathrm{C}\right)$. The initial properties of the pulps determined the individual absolute level of extraction for each setting as the swelling of the carbohydrate structure passed through the maximum range of different settings. The specific level of extraction was found to depend on the initial homogeneity and purity of the pulp measured as content of xylan and PDI. The results indicate that each pulp has different steeping settings that are optimum for the properties of the alkali cellulose or its regenerate. These properties are purity, yield, and degree of transformation. Extracting with $18 \mathrm{wt} \%$ aq. $\mathrm{NaOH}$ for all pulps investigated led to an optimal alkalization result for yield, purity, and conversion. The choice of steeping temperature was found to be important in order to balance the yield and the purity of xylan-containing pulps.

One of the investigated pulps, a short-fiber kraft pulp with a somewhat elevated xylan content, showed the greatest variation in purity and a less pronounced transformation over the investigated range of alkali extractions. It would be of interest to investigate a narrower range of steeping settings that mirror today's viscose production conditions using this pulp as proofof-concept. Moreover, it would be of interest to investigate the extent to which extracted xylan is degraded at temperatures up to $50{ }^{\circ} \mathrm{C}$.

It was also found that the more uncommon analysis of $\mathrm{R} 18$ at $50{ }^{\circ} \mathrm{C}$ gives important information on the practical performance of a dissolving pulp. The results indicated that a lower R18 at $50^{\circ}$ than at $20{ }^{\circ} \mathrm{C}$ is mainly caused by more extensive xylan removal at the higher temperature level and depends on the initial hemicellulose content of the pulp.

Acknowledgments The authors gratefully acknowledge the financial support from the Södra Foundation, Sweden.

Funding Open Access funding enabled and organized by Projekt DEAL.

\section{Compliance with ethical standards}

Conflict of interest The authors declare that they have no conflict of interest.

Open Access This article is licensed under a Creative Commons Attribution 4.0 International License, which permits use, sharing, adaptation, distribution and reproduction in any medium or format, as long as you give appropriate credit to the original author(s) and the source, provide a link to the Creative Commons licence, and indicate if changes were made. The images or other third party material in this article are included in the article's Creative Commons licence, unless indicated otherwise in a credit line to the material. If material is not included in the article's Creative Commons licence and your intended use is not permitted by statutory regulation or exceeds the permitted use, you will need to obtain permission directly from the copyright holder. To view a copy of this licence, visit http://creativecommons.org/licenses/by/4.0/.

\section{Appendix}

See Figs. 6, 7 and 8. 

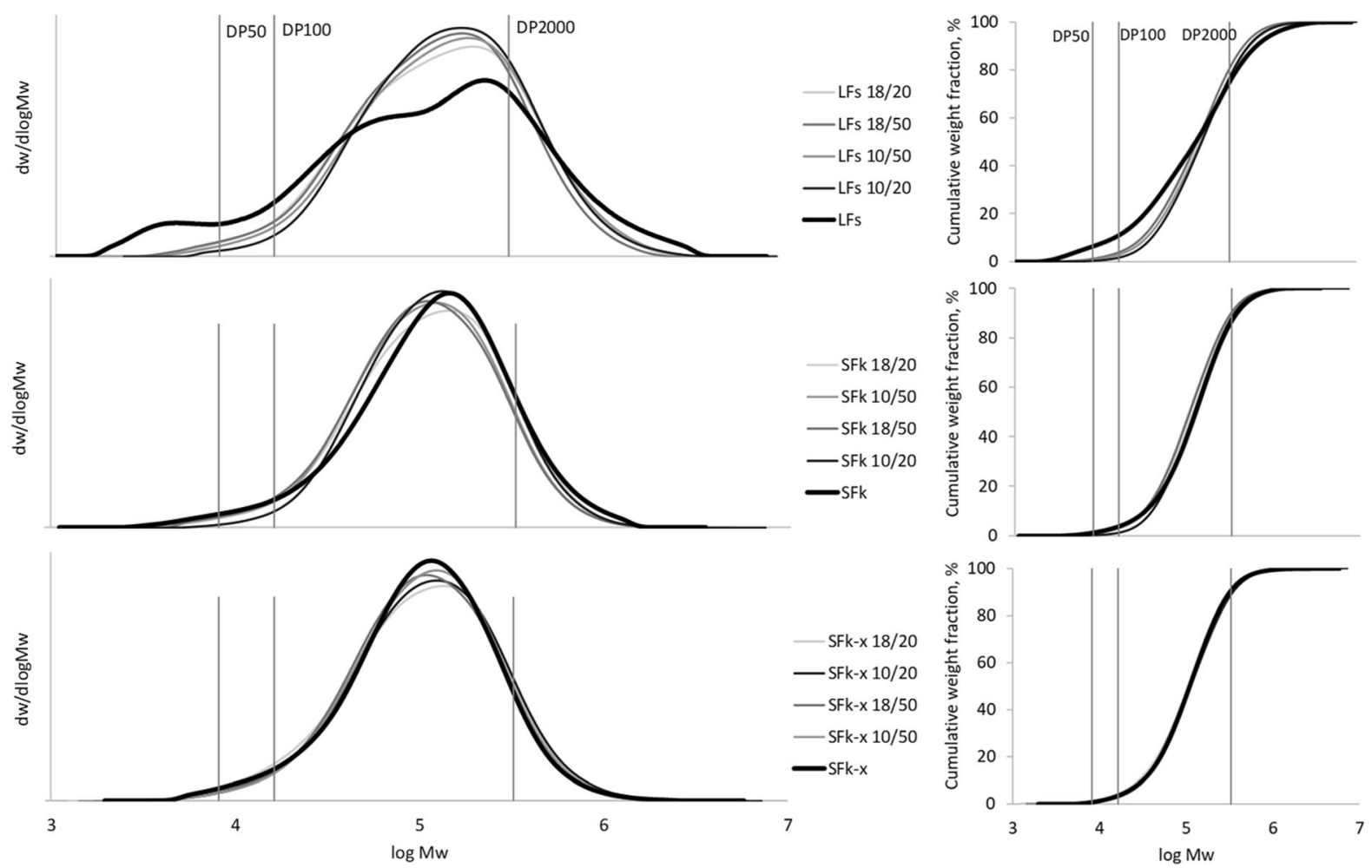

Fig. 6 Molecular weight distribution of pulps (LF-long fiber, SF-short fiber, s—sulphite, $\mathrm{k}$ - kraft, $\mathrm{x}$ - -high xylan) and their temperatures (concentration of aqueous $\mathrm{NaOH} 10$ or $18 \mathrm{wt} \%$; regenerate after alkalization at different concentrations and temperature 20 or $50{ }^{\circ} \mathrm{C}$ ). Left: absolute frequency distribution. Right: cumulative frequency distribution

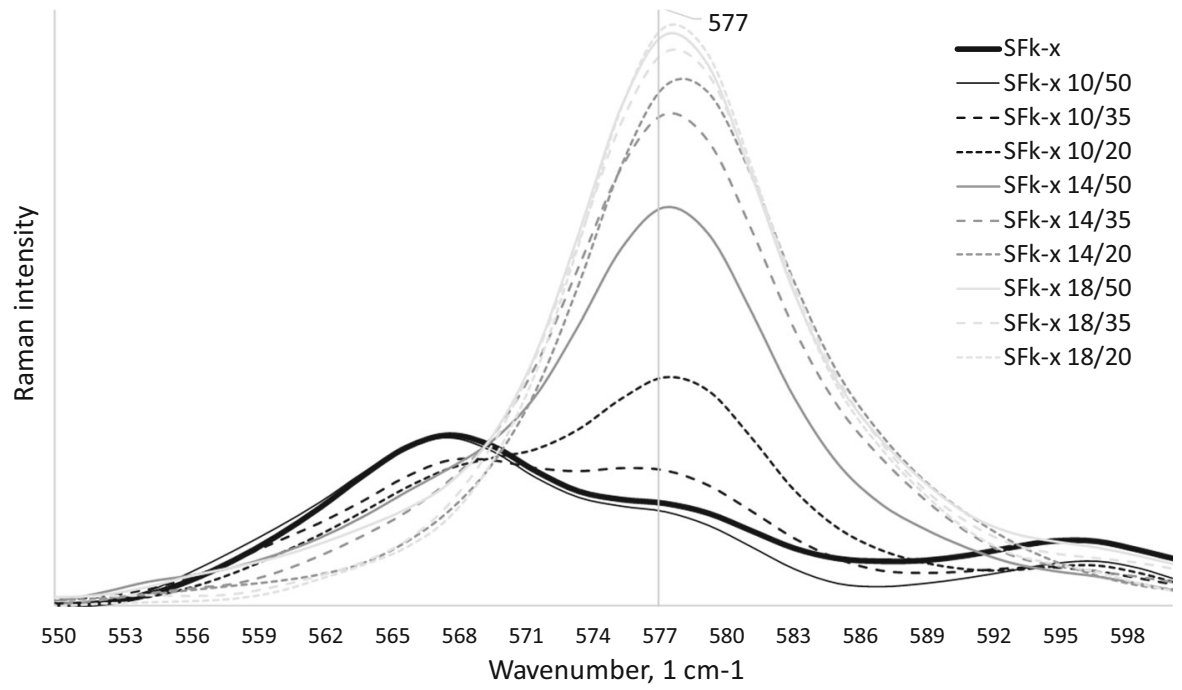

Fig. 7 Raman-intensities at a small selection of wavenumbers for short-fiber kraft pulp (SFk-x) and its alkalized residues. Alkalization was done with 10,14 , or $18 \mathrm{wt} \%$ aq. $\mathrm{NaOH}$ at 20,30 , or $50{ }^{\circ} \mathrm{C}$, respectively 
Fig. 8 Relationship of yield and hemicellulose content in residue after alkali extraction.

Alkalization was done with 10,14 , or 18 wt \% aq. $\mathrm{NaOH}$ at 20,30 , or $50{ }^{\circ} \mathrm{C}$, respectively. a, b LFslong-fiber sulphite pulp; c, d SFk - short-fiber kraft pulp; e, f SFk-X - short-fiber kraft pulp with high xylan
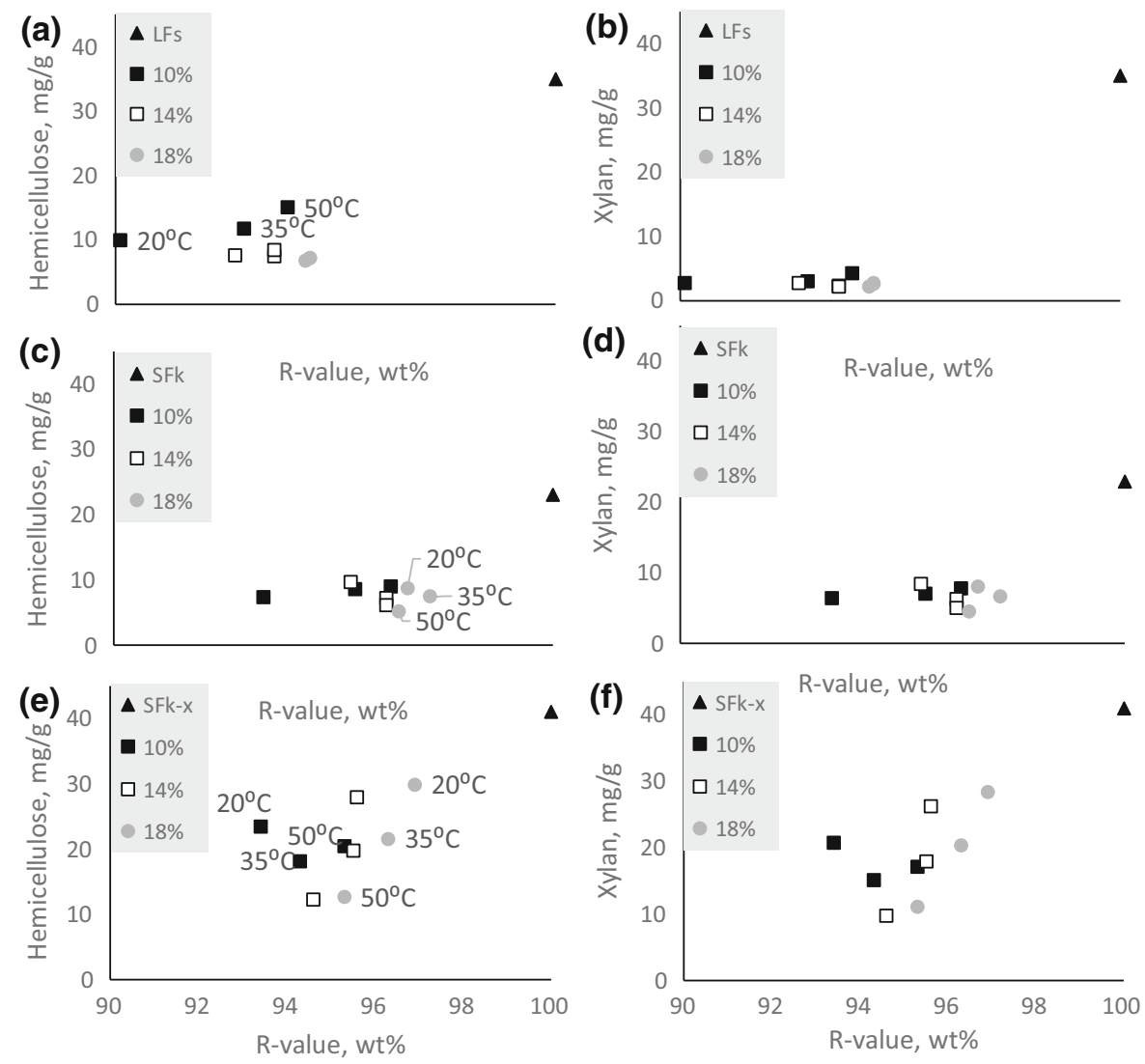

\section{References}

Agarwal U (2017) Chapter 4. Raman spectroscopy in the analysis of cellulose nanomaterials. In: Agarwal U, Atalla R, Isogai A (eds) Nanocelluloses: their preparation, properties, and applications. ACS symposium series. American Chemical Society, Washington, DC

Ellefsen Ö (1955) Nitration as an analytical tool in the study of wood pulps VI. Properties of rayon pulps and influence on filterability. Norsk Skogsindustri 9(11):399-406

Fengel D, Wegener G (1989) Wood-chemistry, ultrastructure, reactions. Walter de Gruyter, Berlin, p 613

Fink HP, Fanter D, Loth F (1982) Röntgen-Weitwinkeluntersuchungen zur Phasenumwandlung bei der Alkalisierung von Cellulose. Acta Polym 33(4):241-245

Götze K (1967) Chemiefasern nach dem Viskoseverfahren, 3rd edn. Springer, Berlin, p 1282

Henniges U, Kostic M, Borgards A, Rosenau T, Potthast A (2011) Dissolution behavior of different celluloses. Biomacromol 12(4):871-879

Heuser E, Bartunek R (1925) Ueber Alkali cellulose II. Cellulosechemie 6(2):19-26

Klemm D, Philipp B, Heinze T, Heinze U, Wagenknecht W (1998) Interaction of cellulose with aqueous and alcoholic solutions of alkali hydroxides. Comprehensive cellulose chemistry. Functionalization of Cellulose, vol 2. Wiley$\mathrm{VCH}$, Weinheim, pp 33-51
Kolboe A (1960) A study of systematic errors in the filtration stage during filterability determinations of viscose. Part I: errors caused by non-constant pressure and viscosity. Norsk Skogsind 14(9):348-353

Kyrklund B, Sihtola H (1963) On the conductrometic determination of the particle size distribution in viscose. Pap Timber 45(4):119-125

Mozdyniewicz D, Nieminen K, Sixta H (2013) Alkaline steeping of dissolving pulp. Part I: cellulose degradation kinetics. Cellulose 20:1437-1451

Mozdyniewicz D, Schild G, Sixta H (2014) Alkaline steeping of dissolving pulp. Part I: soluble compounds in the press lye. Cellulose 21:2889-2900

Pöyry Management Consulting Oy (2017) PöyrySmart Service. Pulp mill search

Reyes D, Skoglund N, Svedberg A, Eliasson B, Sundman O (2016) The influence of different parameters on the mercerisation of cellulose for viscose production. Cellulose 23:1061-1072

Richter G, Glidden K (1940) Cellulose sheet swelling effect of temperature and concentration of sodium hydroxide solutions. Ind Eng Chem 32(4):480-486

Röder T, Mossbauer J, Fasching M, Bohn A, Fink HP, Baldinger T, Sixta H (2006) Crystallinity determination of man-made cellulose fibers-comparison of analytical methods. Lenzing Berichte 86:132-136 
Rydholm S (1965) Carbohydrate removing methods. In: Pulping processes. Wiley, New York, pp 992-1023

Saito GI (1939) The behavior of cellulose in solutions of alkalies. I. Cross-sectional swelling of fibers of different celluloses in sodium hydroxide solutions at different temperatures. Kolloid-Beihefte 49:365-366

Schenzel K, Fischer S, Brendler E (2005) New method for determining the degree of cellulose I crystallinity by means of FT Raman spectroscopy. Cellulose 12(3):223-231

Schenzel K, Almlöf H, Germgård U (2009) Quantitative analysis of the transformation process of cellulose I to cellulose II using NIR FT Raman spectroscopy and chemometric methods. Cellulose 16(3):407-415

Sihtola H, Nizovsky B (1963) The yield in the viscose process compared with the alkali solubility of the pulp. Pap Timber 45(5):299-301

Sisson W, Saner W (1941) The effect of the temperature and the concentration of sodium hydroxide on the $\mathrm{x}$-ray diffraction behavior of raw and of degraded cotton. J Phys Chem 45(5):717-730

Sixta H (ed) (2006a) Pulp purification. Handbook of pulp, vol 2. Wiley-VCH, Weinheim, pp 933-966

Sixta H (ed) (2006b) Pulp properties and applications. Handbook of pulp, vol 2. Wiley-VCH, Weinheim, pp 1009-1067
Sixta H, Borgards A (1999) New technology for the production of high-purity dissolving pulps. Das Pap 53(4):220-234

Sixta H, Schrittwieser A (2004) Alkalization of hardwood dissolving pulps, R\&D Lenzing AG. In: Sixta H (ed) Handbook of pulp (2006a), vol 2. Wiley-VCH, Weinheim, pp $1-10$

Sixta H, Harms H, Dapia S, Parajo JC, Puls J, Saake B, Fink H-P, Röder T (2004) Evaluation of new organosolv dissolving pulps. Part I. Preparation, analytical characterization and viscose processability. Cellulose 11:73-83

Treiber E, Rehnström J, Ameen C, Kolos F (1962) Ueber eine Laboratoriums-Viskose-Kleinstanlage zur Testung von Chemiezellstoffen. Das Pap 16(3):85-94

Woodings C (ed) (2001) Regenerated cellulose fibres. Woodhead Publishing, Cambridge, p 336

Wyatt W (1966) Optimum viscose process studies I. Steeping and pressing. Tappi 49(10):464-468

Young R (2018) World dissolving pulp monitor. Fastmarkets RISI - Market research provider for forest product industry. RISI, Inc., Massachusetts

Publisher's Note Springer Nature remains neutral with regard to jurisdictional claims in published maps and institutional affiliations. 